The Historical Journal, 24, 4 (1981), Pp. 997-1002.

Printed in Great Britain

\title{
OCTOBER AND THE WORLD: THE BOLSHEVIK REVOLUTION AND ITS AFTERMATH
}

October 1917: A Social History of the Russian Revolution. By Marc Ferro. London: Routledge \& Kegan Paul, I980. Pp. xiv $+345 \cdot \ell^{\text {I } 3.50 . ~}$

The Debate on Soviet Power. Edited by John L. H. Keep. Oxford: Clarendon Press, 1979. Pp. xiv $+465 \cdot £$ i 5.00 .

Les premiers communistes français: formation des cadres et bolchevisation. By Danielle Tartakowsky. Paris: Presses de la Fondation Nationale des Sciences Politiques, 1980. Pp. 215.

October and the World: Perspectives on the Russian Revolution. By Paul Dukes. London: The Macmillan Press, 1979. Pp. vii +224. Eı Io.oo.

The history of the bolshevik revolution has long been overshadowed by the continuing topicality of the issues it raises. It is therefore not surprising to find that historians are still fighting the same battles as did the bolsheviks and their rivals, albeit with the pen rather than the sword, spilling ink rather than blood.

In Britain, of course, the debate has been somewhat more oblique. On the one side (in favour of the revolution) stands E. H. Carr, stating cautiously though none the less controversially:

It may well have been true, as the rapid disintegration of the February revolution seemed to show, that bourgeois democracy and bourgeois capitalism on the western model, which was what the Mensheviks wanted and expected, could not be rooted in Russian soil, so that Lenin's policy was the only conceivable one in the empirical terms of current Russian politics. To reject it as premature was to repeat, as Lenin once said, 'the argument of the serf-owners about the unpreparedness of the peasants for freedom '.

On the other side stands Schapiro, angered by what he sees as this unnecessary determinism and absorbed in demonstrating how 'a small, unpopular minority'? (the bolsheviks) seized power and set up a totalitarian regime.

This dichotomy in the historiography of the October revolution still holds fast, and both Marc Ferro's October I9I7 and John Keep's The debate on Soviet power do not really escape its clutches, though Ferro manages to transcend the positions of Carr and Schapiro in a rather interesting way. For whilst he nods in Schapiro's direction with the dubious assertion that the advent of 'the so-called Stalin era' was 'obvious even in 1917 ' (p. 276 ), it is nevertheless a salient feature of his work that he conceives of the revolution as coming from below, cribbed and confined by the harshness of Russian conditions prevalent at the time. And whilst most western historians have chosen to focus almost exclusively on the political level of reality for an explanation of events, Ferro has attempted to dig deeper into Russian society for the roots of the revolution. He is dissatisfied with the idea of revealing merely the viewpoint of 'the leaders of the Revolution, the politicians and the militants',

1 E. H. Carr, The bolshevik revolution, 1917-23, I (Penguin, London, 1973), I 10-I 1 .

2 L. Schapiro, The origins of the communist autocracy (London, 1955), p. 35I. 
and wants also to consider the 'various groups' whose history 'did not necessarily proceed at the same pace as the historical process that occupied the headlines...' (p. vii). But does Ferro really succeed in integrating a history of the Russian masses in 1917 with an account of the events leading to the bolshevik coup that October?

The book is organized into two sections. The first is devoted to the disintegration of the February revolution, the second analyses developments leading to the October revolution. In one sense Ferro's account follows the well-worn path marked out by Chamberlin's classic The Russian Revolution 1917-1921, but in other respects it approaches the subject from a rather different angle. In terms of form, the angle chosen is decidedly awkward. For instead of a carefully woven narrative (in the manner of Chamberlin), we face a much looser and more disjointed framework, with separate themes taken out of sequence and formed into distinct chapters. The reader thus loses a sense of the whole into which these parts fit, and chronology is thrown to the winds until we encounter the October rising in the last chapter. But in respect of substance, Ferro's approach has a great deal to offer, particularly in his discussion of the army, the revolution in the countryside and the role of the factory committees.

The defection of the army was crucial to the collapse of the provisional government which had come into being that February on a wave of high expectations amongst the masses. But the new government failed to stay afloat. The army soon began to fall apart, and with the attempt to crack down on indiscipline in the summer of 1917 , the authorities inadvertently drove the rank-and-file into the arms of the bolsheviks, who alone matched the wildest demands of the rebellious populace. As one soldier wrote (on 9 August 1917 ) : 'Who are these Bolsheviks? What party do they belong to? The government attacks them, but we can't see what's wrong. We used to be against them, because that's what the revolutionary government wanted, but with all those broken promises, we are gradually going Bolshevik ourselves. Send us some information' (p. 82). Whilst in the trenches the soldiers were turning mutinous and looking to the bolsheviks for leadership, in the countryside the peasants went ahead in many places and redistributed the land themselves, essentially acquiescing in the bolshevik seizure of power rather than actively seeking it. As Ferro notes: 'for the peasantry, it was clear that only the "maximalists" - Bolsheyiks and left Socialist Revolutionaries lumped togetherreally approved of what they had done' (p. I 34). In the towns, on the other hand, labour militancy strained at the leash imposed by local soviets (dominated by soldiers' votes), until finally with the achievement of a bolshevik majority in both Petrograd and Moscow, the tether snapped and the provisional government was brought tumbling down, a mere relic of times past.

By October the Bolsheviks had become inextricably entwined in mass organizations - from factory committees to trade unions - pushing towards a new structure of power. For having found that their own 'intellectual guides' of the February days had let them down (p. 144), these organizations fell an easy prey to bolshevik penetration. Thus a coalescence of interests explained the bolshevization of these popular institutions: ' the radicalization of the masses, who followed different watchwords of the extreme left and showed their radicalization instantly, through direct democracy, and the increase in organizational links between these institutions and the Bolshevik party' (p. 203). The October rising was thus 'the outcome of this coincidence of factors - on the one hand, social pressures towards disequilibrium, and on the other the chronic incapacity of the Provisional Government to head off a rising, with Lenin's awareness of this incapacity, and his conviction that a rising was opportune, necessary and beneficial to his own party' (p. 230). 
Lenin receives far less prominence in this process than has customarily been attributed to him by historians on both the right and the left. Even the first acts of repression unleashed by the regime are ascribed not to the bolshevik leadership 'which was occupied in having congress vote for the seizure of power and the appointment of people's commissars' but rather to the members of the committee for the defence of the revolution 'who were, except in Antonov-Ovseyenko's and Podvoysky's cases, humble militants, the NCO's of the revolutionary army. These men', Ferro insists, 'were a part of the insurgent masses as much as of the Bolshevik party, and their acts revealed the masses' will rather than decisions of the central committee or party bodies' (p. 263). The terror, too, is described as originating from below and only encouraged from above (p. 265). Ferro thereby turns upside down the usual picture of the October revolution.

Therein lies the originality of Ferro's work, and even though one is occasionally intrigued by references at the back of the book which do not actually provide authority for some of his assertions, and puzzled by his conception of film as evidence without accompanying qualification (see, for example, pp. 141-4), October 1917 none the less rectifies a grave imbalance further perpetuated by John Keep in his edition of documents entitled The debate on Soviet power.

This is a useful volume containing the minutes of the All-Russian Central Executive Committee of Soviets from October 1917 to January 1918, all assiduously annotated by the editor, who infuses it with a view of the revolution which stands in bleak contrast to that of Ferro. From it we learn the astounding news that the bolsheviks were 'neither by intellectual background nor by practical experience... well equipped to undertake the superhuman task of reconstruction' (p. I I), which leaves one a little bewildered at how all those dams and factories somehow got built. But this is only the first paper in Professor Keep's examination set at advanced level for long-dead Russian revolutionaries. Not only are bolshevik qualifications inadequate (evidently they should not have sat the examination), they fail economics because they disagree amongst themselves on the policy to pursue (p. 14), which is, of course, unknown elsewhere; and here, instead of receiving extra marks for democratic discussion, they are penalized for incompetence. In sociology the candidates persist in talking about a 'class struggle' which Professor Keep apparently believes only exists when people are told about it. In case some misguided souls associated revolutions with violence, we are corrected and reminded that the doctrine of 'class struggle' stood to blame, for it 'perplexed ordinary people' (probably professors of history included) 'or diverted their energies from more constructive activities' as well as stimulating 'deeds of brutal savagery' (P. I 7). And, last but not least, comes the paper on political science, where the bolsheviks lose marks for employing 'manipulative techniques' (unspecified) 'more consistently and with greater sense of purpose' than their rivals (p. 20), which, as we all know, is tantamount to cheating. In fact Lenin's deviousness seems to be Keep's key explanation for the success (or disaster?) of the October revolution, and what is entirely missing from this lurid account is any reference to the existence of mass agitation coming from below, such as Ferro describes, and the beginnings of a civil war, which at least goes some way to explain the establishment of institutions like the Cheka.

Whilst Ferro seeks to liminish Lenin's role, particularly where the initiation of repression is concerned, Keep tends to exaggerate the degree to which he controlled events, and in order to make this credible he presents us with the image of a Lenin almost omniscient in his foresight (see p. 22, with respect to remarks on the soviets) 
and possessed of extraordinary consistency of thought (see p. 23). But the truth would appear to be submerged somewhere in between these two opposing views. For Ferro ignores a crucial feature in Lenin's thought on revolution - namely the impact of the Paris commune and its bloody demise. In an article on the 'Lessons of the commune', published as long ago as March I908, Lenin pointed to two mistakes which the French proletariat made in $187 \mathrm{I}$. Firstly, they tried to act as patriots and thus underestimated the intensity of class antagonisms. Secondly, in displaying 'excessive magnanimity' the proletariat 'underestimated the significance of direct military operations in civil war, and instead of launching a resolute offensive against Versailles that would have crowned its victory in Paris, it tarried and gave the Versailles government time to gather the dark forces and prepare for the blood-soaked week of May'. The lesson for Russians was that 'there are times when the interests of the proletariat call for the ruthless extermination of its enemies in open armed clashes' ${ }^{3}$ The same thought had occurred to Lenin in composing his article on 'The Russian revolution and civil war' in September 1917: '. . we have learned much since the Commune, and we would not repeat its fatal errors, we would not confine ourselves to defence against the Versaillais (or the Kornilovites) but would take the offensive against them and crush them' ${ }^{4}$ Thus with the successful seizure of power, Lenin was in no mood to give quarter. He preferred to err on the side of pre-emptive attack against the enemy rather than cautiously await a repeat of 1871 . This, then, points to a strong element of consistency in Lenin's thinking. But it would be wrong to imply, as Keep does, that Lenin suffered no doubts and that therefore the tide of events did not in itself contribute to the shape of things to come. Indeed, a reading of Lenin's writings during this fateful year reveals a far more uncertain and contradictory mind than one might otherwise suppose.

For the man so bent on seizing power was also the author of 'The State and revolution', a polemic against the idea of adapting the existing bureaucracy for revolutionary purposes. It is here than Lenin talks wistfully about 'the mass of the population' taking 'an independent part, not only in voting and elections, but also in the everyday administration of the State. Under socialism', he claims, 'all will govern in turn and will soon become accustomed to no one governing.' ${ }^{\text {'But he failed }}$ to 'smash the old bureaucratic machine' as he had hoped, ${ }^{6}$ and by the end of 1922 was bemoaning the evils of a bureaucracy which 'we took over from tsarism and slightly anointed with Soviet oil' ${ }^{7}$ Thus there were two Lenins both in 1917 and after - the libertarian socialist as well as the authoritarian revolutionary. Ultimately it was not merely the fact that the bolsheviks had seized power alone, but also the primitive nature of Russian conditions which ensured that authoritarianism would, in practice, predominate over democratic socialism.

These conditions found no counterpart in the west and this was precisely where the tactics which the bolsheviks pursued so effectively in Russia met with such recalcitrance. For the elements in Leninism which least suited western conditions

${ }^{3}$ V. I. Lenin, Collected works, XIII (Moscow, I962), 476.

${ }^{4}$ Ibid. xxvi (Moscow, 1972), 41. $\quad{ }^{5}$ Lenin, Selected works, II (Moscow, 1970), 372-3.

- '... to smash the old bureaucratic machine at once and begin immediately to construct a new one that will make possible the gradual abolition of all bureaucracy - this is not utopia, it is the experience of the Commune, the direct and immediate task of the revolutionary proletariat', ibid. p. 321 .

"The question of nationalities or "autonomisation", 30 Jan. I922, Lenin, Last letters and articles (Moscow, 1971), p. 18. 
were the very ones which had triumphed in October and were then dogmatized for export. But how was it that the west became the reluctant recipient of bolshevik attentions?

The October revolution had been pre-eminently a Russian affair, but there was no way of setting it apart from the rest of the world. Not only had it erupted within a crucial sector of the allied camp during the first world war with an untimely demand for peace, but its protagonists were also committed internationalists and, more importantly, in Lenin this outlook had been strongly reinforced by the experience of revolutionary defeat in 1905 . That fateful year he had boldly and falsely assumed that 'proletarian Europe will make it impossible for the crowned heads of Europe to help the Russian monarchy' ${ }^{8}$ But defeat and the salvaging of the Russian economy by French banks then taught a bitter lesson: 'the Russian revolution can achieve victory by its own efforts, but it cannot possibly hold and consolidate its gains by its own strength. It cannot do this unless there is a socialist revolution in the West. Without this condition restoration is inevitable. '" Thus, as with the shaping of events at home from October 1917 , force of circumstances and a vital element in Lenin's own thinking combined to work towards the same outcome. The bolsheviks, now in power, therefore sought to spread the revolution abroad, and for this purpose eventually set up the Communist International in 1919 , an organization not merely of their own making but inevitably also conceived in their own image. But here lay a fundamental flaw, unseen by many west European revolutionaries (like Bordiga in Italy) who were blinded by the desperate need to build an antithesis to the ramshackle and undisciplined Second International. For bolshevik forms of organization and strategy were successful in Russia precisely because they were peculiarly adapted to Russian conditions, whilst the situation in the west was far more dissimilar than Soviet leaders ever supposed. Yet the bolsheviks persisted in the belief that they held the recipe for revolution in their hands, as Rosa Luxemburg had predicted: 'the danger begins only when they make a virtue of necessity and want to freeze into a complete theoretical system all the tactics forced on them by these fatal circumstances, and want to recommend them to the international proletariat as a model of socialist tactics'. ${ }^{10}$

The history of the French communist party (PCF) provides eloquent testimony to support Luxemburg's contention and one looks to Danielle Tartakowsky's work on Les premiers communistes franfais for some discussion of the problem. But the title is unfortunately misleading. Hardly any live communists actually appear in the book, which is really a detailed and erudite study of party publishing and training schools during the twenties when the comintern was desperately trying to bolshevize the PCF. Although the author explicitly acknowledges the need to link such an abstract theme to the social and political milieu of post-war France (p. I4), the reader is none the less suddenly thrust into a morass of detail about sales figures for party publications and attendance at party schools. One cannot but pay homage to the wealth of knowledge displayed in this arcane area, whilst at the same time regretting a missed opportunity for uncovering vital aspects of PCF policy and policy-making during this period, especially as the author had the privilege of access to party

\footnotetext{
8 'A revolution of the 1789 or the 1848 type?', Lenin, Collected works, vill (Moscow, I962), $25^{8}$.

'The unity congress of the RSDLP', ibid. p. $28 \mathrm{o}$.

${ }^{10}$ Rosa Luxemburg, The Russian Revolution and Leninism or Marxism? (Michigan, 1961), p.
} 79 . 
archives. One looks in vain for a discussion as to why the PCF declined so catastrophically by the end of the twenties, which was debated ad nauseam in the comintern from I 930 to I 93 I. Instead we face an account of the party safely confined within the philosophy which dominated it at the time: assuming that the answer to its problems lay in educating the membership and the masses to a particular point of view, rather than questioning whether this viewpoint was actually valid or relevant to French conditions. And just how important was this propagation of the 'Leninist' orthodoxy? It is striking that the PCF only really takes off as a mass party when its leader, Maurice Thorez, finally breaks ranks in September 1934 and declares for a popular front. Prior to this bolshevization meant a headlong decline into oblivion, in view of the fact that France faced no revolutionary situation and Moscow's prescriptions for tactics bore a closer relevance to Russia in 19 I 7 than to western Europe during the twenties.

The issue of the bolshevik revolution's impact on the world is one of the main themes in Paul Dukes' October and the world which aims to examine the Russian revolution 'in a new manner by taking historical and global factors into account' (evidently in contrast to the approach of Aunt Sally, the well known historian of Russia). But it ends up taking the reader on a Cook's tour of Russian history, which swerves into unexplained detours at the whim of our courier, with additional unscheduled stops in the South Pacific (evidently because he spent 1974 in New Zealand) and the United States (for a short excursion into the unrelated realm of American historiography). But like most multi-city tours it leaves the traveller titillated but unsatisfied at the prospect of seeing so much yet in reality glimpsing so little, and trudging home from the airport with snapshots which, once developed, will be impossible to identify. But then it is still more enjoyable than staying at home, and if Macmillans, the tour-operators, could lower the price from its present level, it might be worth the money, especially as Mr Dukes, the courier, entertains us so much on the way.

But what of 'October's' effect on the world? Narrowly conceived, it had little impact on either east or west. It brought Russian out of the war, but did not result in any basic shift in the allies' prospects, for they won in 1918 . It led to the formation of communist parties abroad, yet failed to spark off any successful revolutions on the bolshevik model. It gave the west a good fright, but that was about all. None the less, the new order it spawned has substantially disrupted the global status quo, providing an alternative model for economic development, making a crucial contribution to the destruction of German fascism - albeit at the price of hegemony over eastern Europe, and acting as the bank and the barracks for revolutionaries the world over. And since this latter activity continues to haunt the citadels of the west, we should not expect controversies over 1917 merely to fade away. 